\title{
Realist Avenues to global International Relations
}

\begin{abstract}
Realism has long been the focus of global IR's criticism, but the former can contribute to the latter and thereby improve explanations of international relations. Global IR criticizes that realism supposedly applies universally, sidelines non-Western perspectives, and misunderstands much of foreign policy, grand strategy, and international affairs. Reviewing global IR's case against realism, however, exposes avenues for realism to complement global IR. Realism can contribute to a more global understanding of international relations through its most recent variant: neoclassical realism (NCR). This newest realism allows for contextualization and historicization of drivers of state behavior. It can embrace and has already been engaging global questions and cases; global thought and concepts; and global perspectives and scholarship. Mapping 149 NCR publications produced by 96 scholars reveals a slow shift in knowledge production away from North America towards Europe and to a lesser extent Asia and Africa. Creative research designs and scholarly collaboration can put realism in fruitful conversation with global IR. This has implications for theory building and inclusive knowledge production in realism, global IR, and the wider discipline. Only when we discover new avenues for realists to travel can they contribute to a more global IR. In turn, if global IR scholars engage realism, they may be better able to address the Western versus non-Western dichotomies they challenge.
\end{abstract}




\section{Introduction}

Realism in International Relations (IR) has spurred investigations into the nature of anarchy, conflict, state behavior, and balance of power as much as it has invited criticism. This holds especially for neorealism, which has attracted criticism of its assumptions, concepts, and evidentiary record. Particularly scathing critiques have been formulated by scholars associated with global IR (Acharya, 2014; Acharya and Buzan, 2019; Chakrabarty, 2000; Clapham, 1996: 3-4; Dunn, 2003: 11-12; Grovogui, 2006: 43-47; Hobson, 2012; Krishna, 2001; Shilliam, 2010; Tickner and Smith, 2020). These scholars criticize realism's claim that its knowledge applies universally: across time, culture, and geographical space. They argue that realism results from and reproduces a Western-centric mode of knowledge production (Buzan, 2016; Hobson, 2012: 188; Ling, 2014: 12; Schmidt, 2014: 468; Thakur, 2015; Tickner, 2013; Tickner and Smith, 2020). They maintain that realism fails to explain much of international relations, silences alternative perspectives and voices, and does not grasp origins of conflicts and the behavior of most members of the international system. Therefore, when global IR scholars develop non-Western knowledge of international relations, they re-open avenues of inquiry into the dynamics of power, politics, and the international previously marred by parochial views.

Given this criticism, simply foregoing an evaluation of realism's relevance for global IR is unsatisfactory. If realists ignore global IR, they overlook opportunities to develop better knowledge and to contribute to a vast new body of research. In turn, if global IR scholars ignore realism, they reproduce the very Western versus non-Western dichotomies that they challenge. They risk that global IR becomes another form of parochial knowledge production. It is thus important to examine where realism can contribute to global IR, how realism relates to non-Western IR, and what this means for IR theory and methodology. Global IR's criticism focuses on realism (W Brown, 2006: 125), meaning that exploring realist avenues towards global IR can be read as a hard case (on hard cases: Eckstein, 2009: 118; King et al., 1994: 209; Levy, 2008: 12). Demonstrating a way forward for realists may thus suggest similar avenues for other approaches paradigmatically open to embracing global IR, including liberalism and constructivism.

We explore avenues to global IR through realism's most recent variant: neoclassical realism (NCR). Neoclassical realists argue that they can explain foreign policy, grand strategy, and international politics that a more parsimonious neorealist account cannot. They usually consider their contribution in light of Western IR (Brawley, 2009; Rathbun, 2008; Ripsman et al., 2016). However, one major challenge NCR faces-just as realism and the wider discipline-lies in the Western-centrism of most of its produced knowledge. When we re-explore realism's origins and suggest that NCR provides avenues to develop global IR, we advance the debate on realism, global IR, and the foundations of IR 
(Acharya and Buzan, 2019). In a focused fashion, this reflects on broader theoretical and paradigmatic divides that emerged recently in the discipline (Kristensen 2018, 256-257; Whyte 2019).

In this article, we propose a new research agenda to extend research on realism and global IR in novel directions. We introduce global IR's case against realism, specifically global IR's suggestion that parochial knowledge production renders neorealism's universalist claims analytically circumspect at best and exclusionary at worst. We turn to realism's newest variant, NCR, and suggest it provides avenues to a more global IR. Mapping 149 NCR publications produced by 96 scholars reveals shifts in knowledge production away from North America and towards Europe and, to a lesser extent, Asia, Latin America, and Africa. We argue that because NCR has a less strict understanding of paradigmatic boundaries compared to neorealism, it can embrace global questions and cases, global thought and concepts, and global perspectives and scholarship. Its use of unit-level intervening variables allows it to broaden its scope beyond the West and take non-Western cases seriously in theory-building (not only testing). It is open to reconsidering a wider canon of non-Western scholarship to conceptualize decision-making processes and state behavior. Finally, we suggest how creative research designs and scholarly collaboration can put NCR in fruitful conversation with the global IR literature. In doing so, NCR can contribute to diversifying disciplinary approaches to core concepts of IR. In the final section we address implications for theory and knowledge production in the NCR and global IR literatures and in the social sciences.

\section{Global IR and the Critique of Realism}

Global IR scholars aim at displacing Western IR's intellectual hegemony in the discipline "by placing it into a broader global context" (quoted from Acharya and Buzan, 2019: 303; also see: Waever and Tickner, 2009: 17). Global IR scholars have long argued that neorealism in particular is deeply flawed because it provides a structural, universalist, and ontologically materialist account of patterns of state behavior. Neorealism claims validity across time, culture, and space. It thus naturalizes the West's problems, concepts, and historical experiences. Hobson suggests that realists develop a framework "grounded within a Western parochial analysis of world politics, wherein intra-Western politics is presented as world politics" (Hobson, 2012: 188). It fails to historicize and contextualize adequately the state, power, anarchy, and conflict. This leads to "subliminal eurocentrism" (Schmidt, 2014: 468). Neorealism can be read, therefore, as an output of colonial and postcolonial modes of knowledge production (Guilhot, 2014; Ling, 2014: 12). It has developed largely as an Anglo-American academic endeavor when the US was uniquely powerful (Acharya and Buzan, 2019; Hoffmann, 1977; Hurrell, 2016: 3-4; Vitalis, 2015). 
This Western-centrism of neorealism is interwoven with Western-centric and elitist modes of knowledge production. Neorealism remains one of IR's most-known and broadly received frameworks. Interrogating alternative lenses might even require a re-definition of the parameters of the discipline. Neorealism is thus argued to exclude and silence voices that interrogate culturally and historically divergent processes. It eradicates culturally or historically divergent experiences and makes the world fit with its framework (Acharya, 2016; Acharya and Buzan, 2007; Chakrabarty, 2000; Shilliam, 2010; Tickner and Waever, 2009). Neorealism describes international relations in universal terms of power, capabilities, and black-boxed states.

If global IR scholars simply asked realism to diversify with non-Western scholars and non-Western cases, neorealism might well constitute an avenue to global IR. After all, neorealism is widely used by non-Western scholars and applied to non-Western cases (Farhi and Lotfian, 2012: 125-134; Nau, 2012: 22; Shambaugh and Xiao, 2012: 51-54; also see: Deng, 1998; Escudé, 2015; Rajagopalan, 1999; Resende-Santos, 2007; Yang, 2013). However, global IR scholars suggest that even if neorealism thusly diversifies, it still reduces the role of the non-Western neorealist to a technician who must employ correctly and test empirically theory developed elsewhere. As Mamdani writes, "colonialism brought with it the assumptions that theory is the product of Western tradition and that the aim of academies outside the West is to apply it" (quoted from Mamdani, 2018: 32; also see: Aydinli and Biltekin, 2018a: 3). Neorealism fails to lend agency to actors and to recognize cultural and historical divergence in its causal mechanisms: "Realism falls like a hood on all variations, across space and time" (Chatterjee, 2017: 6).

One group of scholars therefore wants to dismantle realism, which they perceive as a marginalizing and colonial system of thought. This group argues that realist theories and concepts are foundationally problematic and must be deconstructed (also see: Berenskötter, 2018: 825; Henderson, 2013, 2017: 81-82; Krishna, 2001: 401; Sabaratnam, 2011; Seth, 2011). For example, they argue that concepts central to realism such as 'anarchy' reflect IR's Western bias. Sampson suggests that when conceptualizing anarchy, Waltz maintains "a particular conception of anarchy-tropical anarchy-that portrays the international system as "primitive'" (Sampson, 2002: 429). This conception of primitive originates in a Western colonial view that "[t]he anarchical world-the state of nature-was the preserve of non-Europeans, primitive peoples" (Henderson, 2013: 85-86). Seth and Sabaratnam argue that we must deconstruct problematic concepts and foundational myths regarding IR's origins (Sabaratnam, 2011; Seth, 2011). ${ }^{1}$ From this perspective, extending Western-centric realism with non-

\footnotetext{
${ }^{1}$ This foundational myth relates to the view that the discipline of IR originated in the West in the interwar period. This view suggests that institutionalization occurred through textbooks, chairs, institutes and study programs in American and European universities, all the while "idealists" and "realists" debated war and peace. Critics argue that this view is a myth: thinking and theorizing on international affairs originated beyond the West and predated the interwar period; and Western
} 
Western knowledge is illegitimate: it simply reproduces discourses derivative of Western realism and ignores those features that are absent in or challenge the Western canon (Shahi, 2019a, also for an example on Arthaśāstra; Shani, 2008).

This group's s purpose and process of theorizing differs from that of realism. This group theorizes ontologically and critically: 'who constructed the notion of anarchy, how did they construct it, and for whom?' They point to the biased nature of disciplinary knowledge, knowledge production, and the conceptual and paradigmatic underpinnings of theoretical work (Guzzini, 2013; Jackson, 2010). Theorizing in this way is not unique to global IR or non-Western IR approaches. ${ }^{2}$ However, it does challenge key metatheoretical assumptions of realism. That is, because realism is largely concerned with explanatory and problem-solving theorizing, such as 'how do states operate under conditions of anarchy?' Precisely because explanatory, problem-solving theorizing is imperfect in the social sciences, developing new avenues for explanatory theory to analyze state behavior is possible and desirable. After all, "[w]ithout the ability to verify or dismiss particular theories, we would have no ability to choose between theories to guide our behavior and accumulate knowledge" (Ripsman et al., 2016: 106).

Seeking to improve realist theorizing in such a way requires proceeding with another group of global IR scholars. This group suggests that global IR "subsumes, rather than supplants, existing IR knowledge-including well-known theories, methods, and scientific claims" (quoted from Acharya, 2014: 650; also see: Acharya and Buzan, 2019; Tickner and Smith, 2020). ${ }^{3}$ Global IR does not call for theoretical tribalism where new perspectives fight Western lenses. This group aims to develop and build onto its critique in productive ways. It asks scholars to reconsider Western core paradigms and approaches to international relations, including realism. Realists must therefore "look beyond conflicts induced by national interest and distribution of power and acknowledge other sources of agency, including culture, ideas, and norms" (Acharya, 2014: 650). This means that when we explain state behavior, we can insist on the continued causal importance of anarchy, structural incentives, and the relative distribution of material power on the one hand, and the relevance of subjectivity and agential drivers of non-Western states on the other (Hurrell, 2016: 11).

\footnotetext{
texts and institutions overlooked and actively excluded contributions from non-Western counterparts (on the origins of the discipline of IR and its foundational myths, see: Ashworth, 2014; Biersteker, 2009; de Carvalho et al., 2011; Long and Schmidt, 2005; Schmidt, 2002; Thakur and Vale, 2020; Vitalis, 2015).

${ }^{2}$ For discussions of the prevalence, assumptions, and differences in theorizing international politics and state behavior, including in Western approaches to IR critical of realism, see for example: Berenskötter (2018), C Brown (2013), Cox (1981), Dunne et al. (2013), Guzzini (2013), Jackson (2010), and Keohane (1988).

${ }^{3}$ Considerable debate exists on this issue within the global IR, non-Western, postcolonial and de-colonial literatures. Critics have suggested that global IR thusly understood may suffer from or reproduce biases similar to the Western-centric scholarship it challenges (see W Brown, 2006).
} 


\section{Neoclassical Realism and Global IR}

This reading of the global IR literature raises the following questions: Can realists address and contribute, from within their paradigm, to the intellectual debate around the discipline's Westerncentrism? Can realist theorizing and analysis benefit from this? If so, how and through what avenues?

Some global IR scholars have observed that new realist variants such as NCR have become "more relevant to the non-Western world" because they draw insights from it (Acharya, 2014: 650). As such, realist insights continue to matter for the study of international relations (Schmidt, 2014: 468). Through colonialism as much as through globalization and associated processes of (forced and voluntary) socialization, formerly firmly Western patterns of state behavior have spread across the globe. There is then, at a basic conceptual level, a case to be made for the continued inquiry into notions such as power, anarchy, and balance of power from a realist perspective. How realists describe patterns of state behavior originated in a Western canon, but these patterns are not exclusively Western anymore (Schmidt, 2014: 468).

Realism provides appropriate and generalizable first-cut theories into dynamics of global international relations, because concepts such as anarchy matter beyond the West. The experience of anarchy is shared across the globe in the contemporary system of states, if to differing degrees (Acharya and Buzan, 2007: 288, 293, 2019: 303; Waltz, 1979). Anarchy is here understood as the absence of a "higher ruling body in the international system" (Mearsheimer, 2003/2014: 30). If the system of states is structured by anarchy and characterized by power and uncertainty regarding other states' behavior, it provides states' principal interest in survival and welfare. Of course, states differ in their capabilities and some states may be unable to "at any time use force" (Waltz, 1954/2001: 160). And yet, neoclassical realists argue that the anarchical environment is less strictly determinative than neorealism suggests: it provides leeway even for smaller states to enact policy independently. The experience of anarchy is also modified by system-level factors, and differently for differently placed states. For example, geographic location, new military technology, and the presence and absence of regional alliances influence the way the international environment affects state behavior (Ripsman et al., 2016; Snyder, 1996). Finally, the experience of anarchy is mediated through domestic intervening variables such as decision-makers' perceptions, domestic lobby groups, and resource extractive capacity (Dueck, 2009: 139; Taliaferro, 2006).

When neoclassical realists complement neorealist concepts such as anarchy with domestic intervening variables, they borrow from a tradition that analyzes domestic variables to explain the production of foreign policy, grand strategy, and international politics. Earlier authors analyze, for example, decision-making dynamics, resource extractive capacity, and policy preferences of domestic 
socioeconomic groups (Frieden and Rogowksi, 1996; Gourevitch, 1986; Gowa, 1983; Haskel, 1980; Krasner, 1977). Some authors writing in this tradition have long interrogated non-Western cases. For example, Skocpol argues that former colonial relationships insufficiently explain why intra-state social revolutions occur (Skocpol, 1979). Domestic variables are also employed in classical realism. Classical realists write that state behavior is affected by domestic politics and public support (Carr, 1939/2001: 85-87, 132-145), history and ideology (Kirshner, 2012), domestic institutions' legitimacy (Niebuhr, 1959: 49-66), decision-makers' ability to mobilize resources (Aron, 1966/2009: 52-57), or the quality of diplomatic staff (Morgenthau, 1948/1993: 155-158).

NCR differs from this tradition in its paradigmatic assumptions and therefore in its causal mechanism. NCR prioritizes changes in the systemic distribution of relative material capabilities to explain state behavior. It then considers intervening variables to explain anomalous foreign policy, grand strategy, or macro-patterns of behavior. In so doing, neoclassical realists "explain political behavior that a sparer structural realist theory cannot" (Ripsman et al., 2016: 114). Further, unlike some earlier domestic politics approaches NCR has largely ignored global IR. NCR has also, as elaborated below, mostly been developed as an American (and increasingly also European) body of knowledge.

And yet, NCR may anticipate three potential flaws of non-Western theorizing. If non-Western scholarship is perceived and perceives itself as 'local', decentered knowledge, it risks becoming trapped in an exceptionalist account of international relations. Such an account limits itself to ideas and orientations unique to particular non-Western states (Biersteker, 2009: 311; Hurrell, 2016: 6; Shahi, 2019a: 251). Certainly, there is ample reason to scope theoretical and empirical research around a particular non-Western state; in fact, such research may appropriately counteract IR's "fetishization of abstraction" (Krishna, 2001: 401). However, when scholars scope their research around a particular state, they may overlook potential for comparison and generalization, and even risk losing the critical distance to local practice and power necessary for good scholarship. This in turn reifies difference within the cases between carefully collected and contextualized evidence on the one side positioned against a one-dimensional view of the West or Western theory on the other. It essentializes Western as well as non-Western IR and hinders the development of global IR (Shahi, 2019a: 254). When we posit non-Western experiences and scholarship as valuable only where they differ from their Western equivalents, we reproduce the dichotomies that global IR challenges.

What allows NCR to address these potential shortcomings of non-Western theorizing is that it attempts to theorize progressively and bridge materialism and idealism as well as structure and agency (C Brown, 2013: 488-489; Foulon, 2015; Sears, 2017; C Zhang, 2017: 291). NCR offers a way to operationalize non-Western knowledge and scholars within a realist framework that places causal 
primacy in the material structure of the international environment. If global IR subsumes existing knowledge from realism, it can include patterns of geopolitical competition, security threats, and anarchic conditions. This allows scholars to retain some of the theoretical and methodological advantages of realism all the while they can explore contextual and local factors (Hurrell, 2016: 8).

This allows NCR to maintain a systemic, realist framework and complement it with unit-level variables. These unit-level variables differentiate states, historicize and contextualize behavior, and lend agency to decision-makers. These decision-makers are tasked with deciphering structural incentives that influence their strategic choices. This has required neoclassical realists to move away from neorealism's parsimony and generality. NCR analyzes explicitly how agents translate systemic stimuli into state behavior, rather than treating this translation process as a theoretically separate domain of analysis. Neoclassical realists interpret the limitations that systemic incentives impose on state action less strictly when compared to neorealism. They argue that unit-level variables intervene in the transmission belt between systemic incentives and state behavior, because systemic incentives provide states with "considerable latitude" to articulate their interests: systemic incentives "merely [set] parameters" for state behavior (Lobell et al., 2009: 7). In so doing, neoclassical realists appreciate that decision-makers' response to systemic incentives is problematized in three ways. First, decisionmakers "may not necessarily track objective material power trends closely or continuously" (Rose, 1998: 147). Next, decision-makers may be uncertain how to respond to structural incentives (Kitchen, 2010; Wivel, 2005: 361). Finally, decision-makers are constrained by “domestic political incentives and constraints" which affect the capabilities that governments can extract from society (quoted from Dueck, 2009: 139; also see: Christensen, 1996: 11-13, Lobell et al., 2009: 37; Rose, 1998: 162; Zakaria, 1998: 35-39).

While NCR developed a rich literature on this basis, it has created its knowledge mainly in and on North America. To illustrate this point, consider the 96 scholars who published 149 works on NCR until mid-2019. We mapped this body of theory's temporal and geographical distribution based on the authors' institutional affiliation and empirical case studies (Figure 1; Tables 1, 2, and 3). ${ }^{4}$

\footnotetext{
${ }^{4}$ We selected all publications (journal articles, single-authored books, edited books and book chapters published since 1990 and until June 2019) with "neoclassical realis*" in the title or abstract, and/or which we identify as holding neoclassical realist positions (rather than, for example, critiquing NCR) based on self-identification of authors in the contribution and/or employed concepts and frameworks. We did so via the Google Scholar database and through cross-citations to neoclassical realist work. We noted each author's current institutional affiliation (university or other), state and continent. We also noted for each publication which states were analyzed empirically, for example in case studies (if any). A case study is here included when it is defined as such by the author and/or is analyzed by the author in a separate section in the author's publications. We excluded 'doubles': we used co-authored publications only once in our calculations for the cases. Cases on the same state are counted multiple times if used in multiple publications. Three limitations must be noted: 1) we only selected works written in English; 2) the absence of a worldwide academic research database prohibits a more comprehensive search; and 3 ) there is subjectivity inherent in deciding which contribution counts as neoclassical realist. This database is therefore not
} 
NCR's knowledge originates predominantly from scholars based in North-America and Europe. Of the 96 NCR scholars during 1990-2019, 83 are currently affiliated with or employed by North American and European institutions (Figure 1; Tables 1, 2, and 3). In the 1990s, neoclassical realist scholarship emerged in the US and was developed by a handful of North American scholars. This trend continued during 2000-2009 when American scholars dominated knowledge production, although Europeans started to contribute (Table 1). During 1990-2009, most case studies in NCR publications were on Western states (Table 3). Of the NCR scholars who published NCR works between 2010-2019, the portion affiliated in the US decreased to around 30\%. Here, the main shift occurred from North America towards Europe: the number of NCR scholars who published NCR works between 2010-2019 and were affiliated with or employed by European institutions increased over fivefold. While this intraWestern shift is notable, it underpins the criticism that NCR knowledge production is Western-biased (Table 1).

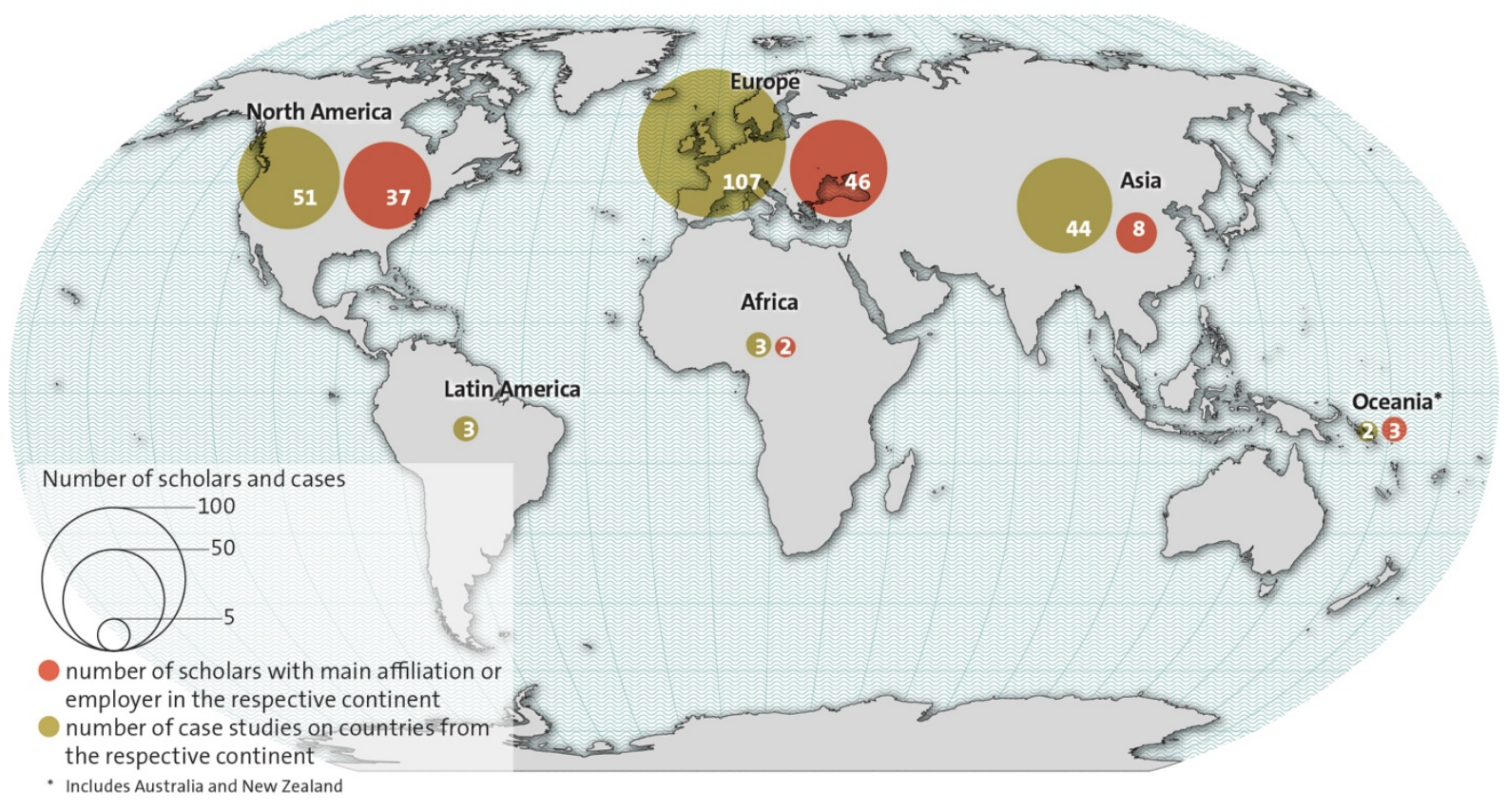

Figure 1. Geographical mapping of NCR by author and case studies, 1990 to June $2019^{5}$

Note: The figures presented in red circles (first in the legend) represent the number of scholars who have their main affiliation or employer in the respective continent and who published NCR works. The figure presented in the green circles (second in the legend) represent the number of case studies from the respective continent used in neoclassical realist work. The figures are based on the database for this article, as outlined above.

Table 1. Number of scholars publishing neoclassical realist works by continent of affiliation and per decade

suggested or intended to be exhaustive or to gate-keep this particular body of work, but to offer a first cut at illustrating the dynamics of knowledge production in NCR.

${ }^{5}$ This image is published under the Attribution-NoDerivs (CC BY-ND) Creative Commons license. 


\begin{tabular}{lccc}
\hline & $1990-1999$ & $2000-2009$ & $2010-2019$ \\
\hline North America & 7 & 15 & 27 \\
Europe & 0 & 7 & 41 \\
Asia & 0 & 0 & 8 \\
Africa & 0 & 0 & 2 \\
Latin America & 0 & 0 & 0 \\
Oceania & 0 & 0 & 3
\end{tabular}

Note: The table presents the number of scholars institutionally affiliated on the respective continent and who published in the respective decade.

Table 2. Number of scholars who published neoclassical realist works, per continent of affiliation, since 1990

\begin{tabular}{lcccccc|cc}
\hline & $\begin{array}{c}\text { North } \\
\text { America }\end{array}$ & Europe & Asia & Africa & $\begin{array}{c}\text { Latin } \\
\text { America }\end{array}$ & Oceania & West & $\begin{array}{c}\text { non- } \\
\text { West }\end{array}$ \\
\hline $\begin{array}{l}\text { Number } \\
\text { of } \\
\text { authors }\end{array}$ & 37 & 46 & 8 & 2 & 0 & 3 & 83 & 13 \\
\hline
\end{tabular}

Note: The table presents the number of scholars institutionally affiliated on the respective continent.

Table 3. Number of case studies per continent, in neoclassical realist works, per decade

\begin{tabular}{lcccc}
\hline & $1990-1999$ & $2000-2009$ & $2010-2019$ & $\underline{\text { Total }}$ \\
\hline North America & 4 & 15 & 32 & 51 \\
Europe & 5 & 31 & 71 & 107 \\
Asia & 5 & 7 & 32 & 44 \\
Africa & 0 & 1 & 2 & 3 \\
Latin America & 0 & 3 & 0 & 3 \\
Oceania & 0 & 0 & 2 & 2
\end{tabular}

Note: The table presents the number of case studies about states in the respective continent used in neoclassical realist research. Not all neoclassical realists employ case studies; some neoclassical realists employ multiple cases within one publication.

Perhaps more telling is the slow shift that takes place towards the non-West. During 2010-2019, an increasing number of NCR scholars are affiliated with or employed by non-Western institutions, especially in Asia (Table 1). More noticeably, the number increased for case studies in NCR publications that analyzed non-Western cases. These non-Western cases comprise especially Asian, and, to a lesser extent, African and Oceanian ones (Table 3). This likely mirrors an increasing preoccupation with the rise of China and the possibility of renewed superpower competition. It offers a starting point to consider how NCR's use of intervening variables may contribute to-and has already started extending research on-global IR. 
Specifically, we argue that NCR can contribute to global IR by providing a generalizable framework within which to order the relative causal impact of systemic stimuli and unit-level intervening variables. NCR can contribute to global IR because it attempts "to explain variations in foreign policy over time and space by supplementing the structural assumptions of neorealism" (Wivel, 2005: 360). NCR's intervening variables are not causally independent but affect state behavior's timing and shape. Neoclassical realists employ intervening variables to examine the influence of culture; identity; perceptions; regime type; domestic constituencies; resource extractive capacity; ideas and beliefs; alliances and strategic interaction; and public opinion and media pressures. ${ }^{6}$

Due in part to this broad thrust, NCR has developed into the new orthodoxy for realists (Narizny, 2017: 155). However, NCR has also attracted criticism from within and outside the approach. Critics argue that NCR lacks theoretical consistency, employs intervening variables ad hoc, and theorizes in a regressive and degenerative manner (Legro and Moravcsik, 1999; Narizny, 2017; Rathbun, 2008; NR Smith, 2018; Wivel, 2005: 367-370). In response, NCR's advocates order their intervening variables in two ways: One is to systematize the intervening variables' likely interaction and influence on state behavior (Ripsman et al., 2016). Another is to categorize the different intervening variables, which highlights the differences and richness within NCR (Onea, 2012; Quinn, 2013; Rathbun, 2008; NR Smith, 2018; Taliaferro, 2000; Wivel, 2005). It is this richness that allows neoclassical realists to speak and contribute to global IR. In the following section, we outline how NCR can engage and develop a more global IR through three avenues: global questions and cases; global concepts and thought; and global perspectives and scholarship.

\section{Global Questions and Cases}

NCR allows for contextualized analysis of intervening variables from global questions and cases. NCR's intervening variables are rooted in the domestic and mediate the global material environment's impact on state action. These intervening variables express elements of subjectivity, hierarchy, and cooperation. They may include individual, institutional, and socioeconomic variables which mediate differently and to differing degrees in different local contexts, periods, and scenarios. For example, the effect of domestic norms, ideas, ideologies, identities, and cultures evidently depends on the historical background, institutional regimes, and ideational landscape of the state in question (Acharya, 2009; Dueck, 2004; Hadfield-Amkhan, 2010; Kitchen, 2010; Schweller, 2018).

\footnotetext{
${ }^{6}$ This literature has developed since the early 1990s in the works of, amongst others, Christensen (1996), Dueck (2004), Dyson (2009), Hadfield-Amkhan (2010), He (2017), Juneau (2015), Kitchen (2010), Larsen (2019), Meibauer (2020), Schweller (2018), K Smith (2016), NR Smith (2016), Steinsson (2017), Sterling-Folker (2009), Taliaferro (2006), Wivel (2005), Wohlforth (1993), and Zakaria (1998).
} 
Neoclassical realists have already started to incorporate domestic and individual intervening variables from global questions and cases. Juneau considers how identity and a status-seeking regime lead Iran to squander opportunities to expand (Juneau, 2015). Sari examines how leaders perceive national interests abroad and anticipate domestic public support at home, to explain Indonesian foreign policy vis-à-vis Muslim and non-Muslim separatist groups outside its borders (Sari, 2019). Moore writes that political identities and institutional regimes constrain South African and Brazilian foreign policy responses to external threats (Moore, 2011). This leads emerging powers to adopt different policies regarding nuclear weapons (Carpes, 2014). Other neoclassical realists explain Chinese foreign and security policy. The intervening variables include China's nationalism (Schweller, 2018) and state society-relations (Sørensen, 2013), its imperial history, and narratives around strong borders (Chand and Danner, 2019: 416). Verma analyzes the interaction and resource policies of India and China regarding oil in West Africa (Verma, 2013). Still others combine neoclassical realist and poststructuralist frameworks to analyze the African response to the 2011 Libya crisis (Gelot and Welz, 2018). And they acknowledge explicitly salient roles of history and culture within NCR's structuralmaterialist lens to analyze the Japanese-Korean quasi-alliance (Cha, 2000; Sherrill and Hough, 2015). This shows that NCR analyzes not only democracies or Western great powers. NCR can contribute to studying great and small powers beyond the West-including postcolonial and authoritarian states (or a combination thereof) (Balci et al., 2018; Becker et al., 2016; Götz, 2017; Gvalia et al., 2019; Wivel, 2016).

Beyond intervening variables pertaining to institutional configurations from global cases, a focus on the individual characteristics of decision-makers reveals their individual subjectivity and lived experience. This affects decision-makers' beliefs, operational codes, and decision-making styles (He, 2017). There should also be ample opportunity to integrate broader societal drivers of decisionmaking, such as class, race, or gender, into a neoclassical realist framework. This invites further reflection on the assumptions, differences and similarities-as well as compatibility-between IR paradigms such as realism and thin constructivism (Barkin, 2003; Jackson and Nexon, 2004: 338; Mouritzen, 2017: 635; Sterling-Folker, 2002: 75).

NCR is comparable to thin constructivism regarding positivist theorizing and bridging meta-theoretical debates about structure-agency and materialism-idealism; but the two approaches differ in important ways. NCR starts with variables pertaining to material reality before it introduces ideational variables. In contrast, thin constructivism's ontological priority of ideas over matter means that it starts with variables pertaining to ideation (Barkin, 2003: 326; Meibauer, 2020; Sterling-Folker, 2002; Wendt, 1999). By this interpretation, NCR provides one path towards global IR different from constructivism. Further, realism presents a harder case than constructivism when it comes to integrating ideational 
or social drivers of state behavior, and thus to developing global IR. As suggested above, global IR's criticism is directed mainly at neorealism. Constructivists may already be quite willing to interact with global IR in terms of their theoretical and paradigmatic predilections. This means that if realism can be argued to provide plausible avenues towards global IR, it provides strong inferential value and generalizability for other approaches in the discipline.

When NCR considers intervening variables from non-Western cases, it opens theoretical space for bottom-up theorizing on drivers of state behavior not currently captured by neoclassical realists. Existing intervening variables might pertain, as outlined above, to parliamentary politics, media pressures, lobby groups, ideology, resource extractive capacity, and public opinion's pressure on government. But these variables may not be applicable in the same way to non-Western cases. For example, Zhang argues that in China rural residents take collective action against their government officials through petitions which the Communist party organizes (C Zhang, 2017: 286). This role of political parties and political participation differs between different states, regimes, levels of government, and policy contexts. And these differences may not be captured by existing variables and causal mechanisms. When scholars employ non-Western cases, they need not use them simply to apply NCR (although that already usefully broadens the comparative range of cases). Rather, when scholars investigate non-Western cases, they can develop new variables that emanate from the case's local context. Such new variables complement existing NCR variables and address issues where existing NCR theorizing is "thin" (Acharya and Buzan, 2017: 364). Scholars can use non-Western cases to inductively develop new variables currently overlooked by NCR (for a similar point, see: Aydinli and Biltekin, 2018b; Diez, 1999). After all, for theory to perform well, the causal stories underpinning it must reflect empirical reality (Mearsheimer and Walt, 2013: 433). A more global NCR better describes the diverse empirical realities at play in international relations.

At this stage, two caveats must be made. First, when neoclassical realists integrate intervening variables from non-Western cases, they cannot lend variables other than systemic stimuli causal force. Neoclassical realists argue that international and domestic variables interact to produce foreign policy choices or systemic outcomes. However, for neoclassical realists the international environment's anarchical nature provides the key impetus for state behavior. Second, neoclassical realists must carefully consider NCR's paradigmatic assumptions. The proliferation of intervening variables in NCR has already led to charges of eclecticism and overreach (Guzzini, 2004; Narizny, 2017). However, NCR is not an eclectic approach in the sense its critics employ. Neoclassical realists usually adhere to a materialist-structuralist ontology and soft positivist epistemology-that is, they acknowledge that social reality imposes limits on what can be known and what variables can be controlled (HadfieldAmkhan, 2010: 11-12; Ripsman et al., 2016: 106). Further, they usually assume at least some 
rationality in decision-making and state behavior (for example Juneau, 2015: 220). Neoclassical realists can include new intervening variables from non-Western cases pertaining to, for example, socially produced ideas or cultural practices (Sterling-Folker, 2002, 75-77). However, this requires neoclassical realists to carefully conceptualize these variables to avoid charges of degeneration and regressive theorizing.

\section{Global Concepts and Thought}

An equally important avenue of how NCR can contribute to global IR relates to NCR's openness to broaden the canon of realist concepts and thought. NCR returns to classical realist writing on concepts such as power, interests, morality, and the role of the decision-maker in driving foreign policy. It is also open to new thought, baselines, and foundational texts. In its intellectual roots, realism as conventionally used and taught in IR today originates in and largely is a product of Western thought and the European historical experience. Realists frequently hark back to thinkers such as Weber, Carr, Niebuhr, and Morgenthau. And yet, recent scholarship highlights the importance of non-Western thinkers and their frequently overlooked contributions to concepts such as power, force, statehood, and anarchy (Acharya, 2014: 648; Johnston, 2012; Shilliam, 2010; K Smith, 2018; Tickner and Waever, 2009). This points to more innovative understandings of what thought and concepts constitute realism. Islamic mirrors for sultans and Ibn Khaldun's writings may be used to interrogate concepts such as hegemony or balance of power; to examine the ideational influence of Islam and Islamic society regarding sovereignty; or to conceptualize the ontological divide between the international and the domestic levels (Blaydes et al., 2018; Kalpakian, 2008). Indian scholarship on international relations has grappled with themes associated with realism, for example in Kautilya's writings (Alagappa, 2011; Ollapally and Rajagopalan, 2012, Shahi, 2019b). In the early 20th century, Benoy Kumar Sarkar contributed on utopia, world politics, and the balance of power (Sarkar, 1919). These scholars contribute to concepts and thought conventionally associated with classical realism, but they do so for example through readings of Hindu scripture. Yet other authors combine classical realist thinkers such as Hobbes with postcolonial thought to explain conflict in the 'Third World' (Ayoob, 1997, 2002).

It is not our contention that non-Western concepts and thought on international relations and foreign policy are a new phenomenon. Instead, we argue that NCR is more open than neorealism-and more open than a misreading of global IR might suggest-to reconsider realist thought and concepts through non-Western foundational texts. This does not mean that neoclassical realists must relax their commitment to soft positivism. Rather, neoclassical realists can integrate context-specific and timespecific thought and concepts to analyze state responses to systemic pressures. And this integration of context- and time-specific insights extends to reconsidering realism's foundational texts. In doing 
so, neoclassical realists allow non-Western thought and concepts to translate more directly and more easily into the discipline.

Considering non-Western thought and concepts through a neoclassical realist lens comes with a caveat. Where scholars reconsider past thinkers, they must not read them in a simplified, post-hoc manner but with contextual awareness. When ancient Hindu texts analyze balancing power, in what ways is their conception of power similar to a modern realist? Just as other IR scholars, neoclassical realists should resist the temptation to add authors to their canon superficially, to find what they want to find (just in Sun Tzu rather than Clausewitz). This requires that scholars examine carefully how past thinkers conceptualize concepts such as power and explain the inevitable limits of how their interpretation.

\section{Global Perspectives and Scholarship}

A closely linked avenue of how NCR can contribute to global IR is by bringing regional and local perspectives and non-Western scholarship to bear on the analysis of international relations. To do so effectively necessitates scholars to develop creative research designs and collaborate across disciplines and area studies. This allows scholars to better explain empirical puzzles and conceptual questions. In the following paragraphs we discuss problems inherent in current perspectives and scholarship. We discuss an example from research about Chinese foreign policy that shows the merits of NCR for global IR, and we briefly delve into theoretical and scholarly implications.

Various studies on non-Western powers are conducted from a positivist and neorealist viewpoint, for example on China's foreign policy. However, postcolonial scholars argue that Western analyses are biased in their conception of China as an aggressive, hostile power (Vukovich, 2011). When neorealists examine how China responds to Asia-Pacific security dynamics, they dismiss first-image and secondimage analyses of local Chinese dynamics (Mearsheimer, 2003/2014). Instead, we can treat the nonWest (here, China) not simply as a study object but as a knowledge source. In doing so, we open a line of inquiry for novel insights from non-Western centric perspectives and scholarship. Importantly, we then explain non-Western responses to systemic incentives better. Neorealists assume, for example, that China responds automatically and in a predetermined way to systemic stimuli. NCR, however, allows us to examine carefully China's history, culture, institutional setup, and elites' views about American foreign policy. A neoclassical realist analysis might explain how these factors interact with China's response to systemic incentives in ways unexplained by neorealist approaches. It starts with neorealism's causal primacy of systemic incentives such as East Asia's international environment. This starting point unites neoclassical realists (Rathbun, 2008: 312). Then it examines how domestic 
variables transmit systemic incentives and produce foreign policy choices or long-term patterns of behavior - including of non-Western states, be they great powers or smaller states.

This stepwise introduction of global perspectives and scholarship encourages scholars to develop innovative research designs and to collaborate across disciplines, area studies, and scholars placed in the West and non-West. In turn, this requires scholars to extend their networks, associations, and exchange from their standard disciplinary bases. Currently, such networks often comprise the US, Europe, and Australia/New Zealand (Kristensen, 2018). They might also span states in Asia, Africa, and Latin America which neoclassical realists study. Gvalia, Lebadnize, and Siroky use primary documents and elite interviews with local decision-makers to assess neorealism's and NCR's explanatory power for Georgian foreign policy (Gvalia et al., 2019). Korolev and Portyakov investigate Chinese and Russian responses to international crises in respectively post-Soviet and Chinese spheres (Korolev and Portyakov, 2018). Collaborations along these lines frequently start with a realist framework and then complement it with relevant area expertise.

Such scholarship has far-reaching implications. First, it elucidates how non-Western states respond similarly or differently to similar systemic incentives. It broadens the inquiry to examine how unit-level practices translate systemic incentives into foreign policy and grand strategy. It is based on coproduction, co-authorship, and innovative research designs. This includes comparative analysis, historical case studies, and quantitative and qualitative discourse analysis. Second, it facilitates knowledge production that better explains foreign policy and strategies of non-Western states. In that way, NCR can address issues concerning elitist modes of knowledge production that normalize the West's experience of international relations. This incentivizes scholars to cooperate between discipline and area, because local experts can presumably reproduce better those local contexts that elucidate non-Western states' responses to systemic pressures. Such cooperation is associated with greater innovation across research fields (Whyte 2019, 440). Third, beyond the localization of existing frameworks, such scholarship can take seriously contextual bottom-up perspectives to theory building (not only to theory testing). It can reverse the disciplinary one-way street that applies theory from the West to the non-West. That is, because it is open to agential and contextual variation within the umbrella of the global and geostrategic. This allows for a global conversation as "an evolving debate between scholars, within and across disciplines" (Mamdani, 2018: 32). In such a global conversation, scholars can appraise more fully the respective roles of geopolitical forces on the one hand and local, contextual factors and knowledge on the other.

We do not suggest that contributions to a more global IR must travel NCR's avenues; instead, we argue that NCR provides one viable way to do so. NCR has the scope and theoretical openness to engage 
and contribute to global IR, to encourage greater diversity in the sources of knowledge production, and to inspire interaction and exchange among scholars. From within its paradigm NCR can contribute to global IR and participate in the intellectual debate around the discipline's Western-centrism. This has implications for knowledge production and theory building in the social sciences.

\section{Implications for Knowledge Production and Theory Building}

We started with the case against neorealism developed out of the global IR literature. We proposed that realism provides avenues to explain conflicts, state behavior, and recurring patterns of international politics. These avenues allow specific and historicized explanations also of non-Western states as well as smaller powers. Taking global IR's challenge seriously encourages creative research designs and scholarly collaboration. This contributes to diversifying disciplinary approaches to core concepts of IR. It improves knowledge production and application in the NCR as well as the global IR literatures. And it tells us much about knowledge production and the performative aspect of power in the social sciences.

On the one hand, neoclassical realists must embrace a broader understanding of agency. This includes non-Western states' processes, behaviors, and their potentially system-wide effects. Neoclassical realists have, since NCR's inception in the early 1990s, focused on states' foreign policy and grand strategy. More recently, some neoclassical realists began to develop a theory of international politics. They argue that individual states' grand strategies have system-wide effects: what individual states do affects the international environment for all other states in the system. Thus, NCR may explain foreign policy (Type I NCR), grand strategy (Type II), and systemic outcomes (Type III; Ripsman et al., 2016). Debates then center on which political phenomena Type III explains and how these phenomena are produced. If neoclassical realists want to develop a neoclassical realist theory of international politics - and not just a Western variant-they must engage with and incorporate the many origins of $I R$, of realism, and of its core concepts. If they fail to do so, they risk perpetuating the Western, parochial, and great power biases that permeate the discipline. If neoclassical realists fail to incorporate IR's many origins, they overlook the drivers and patterns of behavior of most members of the international system.

On the other hand, if global IR scholars want to develop a better and more inclusive IR, they must avoid producing knowledge in ways that are disengaged from or supplant existing Western theories, concepts, and methodologies. If global IR scholars leave their relationship with realist thought underdeveloped, they risk continuing the very dichotomies between Western and non-Western IR that they challenge. This reifies some of the disciplinary divides between positivist/post-positivist and quantitative/qualitative research (Kristensen, 2018: 257; Whyte, 2019). 
This means that exploring realist avenues to global IR tells us something about inclusive knowledge production in the social sciences. Knowledge production, here on realism, is what scholars do through repetitive practice. When realists cite Morgenthau, Carr, and Niebuhr (and not, for example, Ibn Khaldun, Sarkar, or Zhang Wenmu), they may not reflect on what the knowledge on realism is. Instead, they may well follow what became a performative act by a dominant group of academics who in turn follow hegemonic social conventions in the field (reified through citations, textbooks, and syllabi). This practice supports the status quo on what knowledge is authoritative and 'good'. It marginalizes and silences alternative voices on diverse cases and origins of knowledge.

Correspondingly, contemporary realists must consider their positionality. Neoclassical realists have already undertaken first steps towards grappling with subjectivity, measurability, and reflexivity. So far, they have clarified limitations in positivist research: how social reality imposes limits on what can be known and what variables can be controlled. Accordingly, most neoclassical realists uphold a soft positivist epistemology (Ripsman et al., 2016: 105-107). Yet some have started to interrogate how they can combine NCR with post-positivist and post-structuralist approaches (Gelot and Welz, 2018). This goes some way to heeding Wæver and Tickner's warning, who write on non-Western challenges to IR that "[w]ithout epistemology, we simply reproduce dominant strains of IR, only in a reflexive format" (Waever and Tickner, 2009: 18). The next step might well include rethinking carefully the realist's own positionality vis-à-vis her study objects as well as the concepts and knowledge she receives, produces, and reproduces. As Acharya and Buzan write, IR is "a two-way street. IR ... prioritizes some things over others, and adds labels and concepts ... that in turn influence how people understand the world they are in and therefore shapes how they act" (Acharya and Buzan, 2019: 7; also: Alejandro, 2019: 3, 10). This article illustrates, then, through the cases of realism, global IR, and the discipline more broadly, how theory building can engage with such epistemological questions. It opens pathways to challenge dominant narratives, to advance a more inclusive discipline, and to improve explanations of state behavior around the world.

\section{Conclusion}

We propose extending research on realism and global IR in novel directions. Having introduced the case against realism from global IR's perspective, we propose how realism's recent variant-NCRprovides avenues to engage and develop global IR.

The case from global, postcolonial and non-Western IR against realism relates to universal and ahistorical claims, to denying agency to actors, and to parochial knowledge production. This means that neorealism in particular may be inadequate to explaining the problems and dynamics of conflict, actors, and processes in global international relations. Because realism is the focus of global IR's 
criticism, exploring realist avenues towards global IR serves as a hard case. If a variant of realism offers plausible avenues towards global IR, it may illustrate how other approaches to international relations can engage non-Western IR and contribute to a more global discipline.

NCR is a recent variant of a scholarly tradition that re-introduces domestic politics into systemic analysis: a variant that has largely ignored global IR. Responding and contributing to the growth of non-Western theories in IR enriches NCR. It opens NCR to considering and integrating global cases, questions, thought, and scholarship. This is possible because NCR is less bound to universalist and structural-materialist theorizing than neorealism is. NCR bridges structure and agency in mid-level theory and reduces theoretical parsimony. It is rich in intervening variables, causalities, and methodologies, meaning that the approach is well-placed to engage global IR insights. These insights relate to the analytical importance of contextuality and placed-ness (in time and space) in a systemlevel approach. This not only brings additional explanatory power and descriptive accuracy; it also broadens the scope of potential inquiry. It responds meaningfully to Chakrabarty's claim that Western thought remains "indispensable and inadequate" (Chakrabarty, 2000: 16).

NCR allows researchers to incorporate mediating effects of intervening variables pertaining to domestic norms, ideas, ideologies, identities, and cultures in system-level analyses. These intervening variables depend on the historical background, institutional regimes, and ideational landscape of the state in question. Opening the realist canon to non-Western political thought helps to grasp the roots of these dynamics and to conceptualize their effects. While this requires a careful reading of conceptualization and meaning in non-Western political thought, it provides fertile common ground to develop global perspectives and cases within an NCR framework. Within NCR, local dynamics cannot replace or predominate system-level variables as causal drivers of state behavior. Indeed, NCR's potential to contribute to global IR does not require relaxing NCR's structural-materialist ontology or soft positivist epistemology. It also does not necessitate loosening NCR's implicit bounded rationality assumption in decision-making and state behavior.

Mapping of 96 NCR scholars and 149 publications illustrates that NCR knowledge production has been dominated by North American scholars but is slowly shifting towards Europe and Asia. We propose putting into fruitful conversation Western approaches such as realism with non-Western approaches via the route of NCR. This encourages differently situated scholars to contribute to global IR. NCR's avenues to global IR encourages creative research design, scholarly collaboration, and bottom-up theorizing. NCR holds much potential to generate greater insights into how non-Western states respond to systemic incentives, and to combine different regional expertise and methodological approaches. In these ways, NCR opens new avenues of inquiry into the dynamics of power, politics, 
and the international previously marred by parochialism. This brings possibilities for NCR to contribute to a vast new body of research. It solidifies NCR's relevance in a discipline that becomes increasingly critical of Western and great power biases. Finally, it broadens the scope and deepens the quality of analytical inquiry. This improves NCR as a theoretical framework.

Exploring realist avenues to a more global IR should not be read as a reification of some notion of essential difference between Western and non-Western theories. Such essentialization would suppose that Western knowledge is universal and non-Western knowledge adds localized expertise. Of course, non-Western scholars produce knowledge that claims universal applicability. Some scholars discuss concepts and phenomena similar-and even complementary-to Western realism (cf. Ayoob, 1997; Balci, 2015; Behera, 2010; Frasson-Quenoz, 2016; Inoguchi, 2009). Others offer different ontologies, explanations, prescriptions, and knowledge claims which challenge positivism, structuralism, materialism, and the centrality of realism's core concepts (e.g. Rösch and Watanabe, 2017; Shahi, 2018, 2019a; Tieku, 2012; Tingyang, 2006). Either way, non-Western scholarship does not offer better knowledge simply because it originates elsewhere. Assuming that it does would preserve dichotomies between Western and non-Western knowledge and essentialize the latter in ways that global IR scholars set out to challenge (W Brown, 2006: 128). When we open NCR to global IR and vice versa, we contribute directly towards better theory in general. As suggested above, such opening needs to come with an awareness that questions and concepts may not travel easily (Biersteker, 2009: 324). Adequately reflecting on such cross-fertilization most likely requires scholars to collaborate across fields of expertise, cases, and theoretical orientation.

Exploring new realist avenues to global IR need not aim simply to "whitewash" realism. It allows scholars to integrate insights from global IR into a neoclassical realist framework. However, realism allegedly creates and maintains parochial modes of knowledge production. It is argued to legitimize knowledge that normalizes a predominantly Western experience of the international as universally valid and good science. So, depending on one's stance on this debate, is opening realism to global IR and vice versa a legitimate exercise? A more open version of realism, that is, one that acknowledges and integrates global questions, cases, and perspectives, might promise a normatively more defensible direction in realist theorizing. ${ }^{7}$ We have foregone further discussion of this question, not because we deem it unimportant but because it is theoretically and metatheoretically separate.

Exploring new avenues to explain international relations is a prerequisite for developing a more global IR. It allows a reconsideration of realism and global IR for inquiry, theory, and knowledge production.

\footnotetext{
${ }^{7}$ See also C Zhang (2017: 291) and F Zhang (2012: 96-97) for an argument to render realism more normatively defensible, focusing on Confucian morality and realism.
} 
Travelling these new avenues and fleshing them out conceptually and empirically should be of interest to realists in a discipline increasingly critical of Western bias; and to global IR scholars grappling with the very dichotomies between West and non-West they set out to challenge. 


\section{Bibliography}

Acharya A (2009) Whose Ideas Matter? Agency and Power in Asian Regionalism. Ithaca: Cornell University Press.

Acharya A (2014) Global International Relations (IR) and Regional Worlds: A New Agenda for International Studies. International Studies Quarterly 58(4): 647-659.

Acharya A (2016) Advancing Global IR: Challenges, Contentions, and Contributions. International Studies Review 18(1): 4-15.

Acharya A and Buzan B (2007) Why is there no non-Western international relations theory? An introduction. International Relations of the Asia-Pacific 7(3): 287-312.

Acharya A and Buzan B (2017) Why is there no Non-Western International Relations Theory? Ten years on. International Relations of the Asia-Pacific 17(3): 341-370.

Acharya A and Buzan B (2019) The Making of Global International Relations: Origins and Evolution of IR at Its Centenary. Cambridge: Cambridge University Press.

Alagappa M (2011) International Relations studies in Asia: distinctive trajectories. International Relations of the Asia-Pacific 11(2): 193-230.

Alejandro A (2019) Western Dominance in International Relations?: The Internationalisation of IR in Brazil and India. London: Routledge.

Aron R (1966/2009) Peace and War: A Theory of International Relations. New Brunswick: Transaction Publishers.

Ashworth L (2014) A History of International Thought: From the Origins of the Modern State to Academic International Relations. London: Routledge.

Aydinli E and Biltekin G (2018a) Introduction: Widening the World of IR. In: Aydinli E and Biltekin G (eds) Widening the World of International Relations: Homegrown Theorizing. London: Routledge, pp. 1-12.

Aydinli E and Biltekin G (eds) (2018b) Widening the World of International Relations: Homegrown Theorizing. London: Routledge.

Ayoob M (1997) Defining Security: A Subaltern Realist Perspective. In: Krause K and Williams MC (eds) Critical Security Studies: Concepts and Strategies. London: Routledge, pp. 121-148.

Ayoob M (2002) Inequality and Theorizing in International Relations: The Case for Subaltern Realism. International Studies Review 4(3): 27-48.

Balci A (2015) Knowledge, Repetition and Power in Ibn al-'Arabi's Thought: Some Preliminary Comments on Methodology. All Azimuth: A Journal of Foreign Policy and Peace 4(1): 39-50.

Balci A, Kardaş T, Ediz I, et al. (2018) War Decision and Neoclassical Realism: The Entry of the Ottoman Empire into the First World War. War in History. DOI: 10.1177/0968344518789707.

Barkin JS (2003) Realist Constructivism. International Studies Review 5(3): 325-342. 
Becker ME, Cohen MS, Kushi S, et al. (2016) Reviving the Russian empire: the Crimean intervention through a neoclassical realist lens. European Security 25(1): 112-133.

Behera NC (2010) Re-imagining IR in India. In: Acharya A and Buzan B (eds) Non-Western International Relations Theory: Perspectives on and Beyond Asia. London: Routledge, pp. 92116.

Berenskötter F (2018) Deep theorizing in International Relations. European Journal of International Relations 24(4): 814-840.

Biersteker TJ (2009) The parochialism of hegemony: challenges for "American" International Relations. In: Tickner AB and Waever O (eds) International Relations Scholarship Around the World. London: Routledge, pp. 308-327.

Blaydes L, Grimmer J and McQueen A (2018) Mirrors for Princes and Sultans: Advice on the Art of Governance in the Medieval Christian and Islamic Worlds. The Journal of Politics 80(4): 1150-1167.

Brawley MR (2009) Analytical Liberalism Versus Neo-Classical Realism: Domestic Politics and British Foreign Policy, 1900-1914. Available at: http://papers.ssrn.com/abstract=1451538 (accessed 21 October 2019).

Brown C (2013) The poverty of Grand Theory. European Journal of International Relations 19(3): 483-497.

Brown W (2006) Africa and International Relations: a comment on IR theory, anarchy and statehood. Review of International Studies 32(1): 119-143.

Buzan B (2016) Could IR Be Different? International Studies Review 18(1): 155-157.

Carpes M (2014) From breadcrumbs to threads of wool: Building a neoclassical realist approach for the study of regional power nuclear choices. University of Hamburg, Hamburg. Available at: http://ediss.sub.uni-hamburg.de/volltexte/2016/7705/pdf/Dissertation.pdf (accessed 22 November 2018).

Carr EH (1939/2001) The Twenty Years' Crisis, 1919-1939: Reissued with a New Preface from Michael Cox. Cox M (ed). London: Palgrave Macmillan.

Cha VD (2000) Abandonment, Entrapment, and Neoclassical Realism in Asia: The United States, Japan, and Korea. International Studies Quarterly 44(2): 261-291.

Chakrabarty D (2000) Provincializing Europe: Postcolonial Thought and Historical Difference. Princeton: Princeton University Press.

Chand B and Danner LK (2019) Between a Rock and a Hard Place: Border Minorities in China's Foreign Relations with South Asia. Journal of Borderlands Studies 34(3): 413-431.

Chatterjee S (2017) Western Theories and the non-Western World: A Search for Relevance. South Asian Survey 21(1-2): 1-19.

Christensen TJ (1996) Useful Adversaries: Grand Strategy, Domestic Mobilization, and Sino-American Conflict, 1947-1958. Princeton: Princeton University Press. 
Clapham C (1996) Africa and the international system: The politics of state survival. Cambridge: Cambridge University Press.

Cox RW (1981) Social Forces, States and World Orders: Beyond International Relations Theory. Millennium 10(2): 126-155.

de Carvalho B, Leira H and Hobson JM (2011) The Big Bangs of IR: The Myths That Your Teachers Still Tell You about 1648 and 1919. Millennium 39(3): 735-758.

Deng Y (1998) The Chinese Conception of National Interests in International Relations. The China Quarterly 154: 308-329.

Diez T (1999) Riding the AM-track through Europe; or, The Pitfalls of a Rationalist Journey Through European Integration. Millennium 28(2): 355-369.

Dueck C (2004) Ideas and Alternatives in American Grand Strategy, 2000-2004. Review of International Studies 30(4): 511-535.

Dueck C (2009) Neoclassical realism and the national interest: presidents, domestic politics, and major military interventions. In: Lobell SE, Ripsman NM, and Taliaferro JW (eds) Neoclassical Realism, The State, and Foreign Policy. Cambridge: Cambridge University Press, pp. 139-169.

Dunn K (2003) Imagining the Congo - The International Relations of Identity. Basingstoke: Palgrave Macmillan.

Dunne T, Hansen L and Wight C (2013) The end of International Relations theory? European Journal of International Relations 19(3): 405-425.

Dyson SB (2009) The Blair Identity: Leadership and Foreign Policy. Manchester: Manchester University Press.

Eckstein H (2009) Case Study and Theory in Political Science. In: Gomm R, Hammersley M, and Foster P (eds) Case Study Method: Key Issues, Key Texts. London: SAGE Publications, pp. 118-164.

Escudé C (2015) Realism in the Periphery. In: Domínguez JI and Covarrubias A (eds) Routledge Handbook of Latin America in the World. London: Routledge, pp. 45-57.

Farhi F and Lotfian S (2012) Iran's Post-Revolution Foreign Policy Puzzle. In: Nau HR and Ollapally DM (eds) Worldviews of Aspiring Powers: Domestic Foreign Policy Debates in China, India, Iran, Japan, and Russia. Oxford: Oxford University Press, pp. 114-145.

Foulon, Michiel (2015) Neoclassical Realism: Challengers and Bridging Identities, International Studies Review 17(4): 635-661.

Frasson-Quenoz F (2016) Latin American Thinking in International Relations Reloaded. Oasis 23: 5375.

Frieden JA and Rogowksi R (1996) The Impact of the International Economy on National Policies: An Analytic Overview. In: Keohane RO and Milner HV (eds) Internationalization and Domestic Politics. New York: Cambridge University Press, pp. 25-47. 
Gelot L and Welz M (2018) Pragmatic eclecticism, neoclassical realism and post-structuralism: reconsidering the African response to the Libyan crisis of 2011. Third World Quarterly 39(12): 2334-2353.

Götz E (2017) Enemy at the Gates: A Neoclassical Realist Explanation of Russia's Baltic Policy. Foreign Policy Analysis 15(1): 99-117.

Gourevitch P (1986) Politics in Hard Times: Comparative Responses to International Economic Crises. Ithaca: Cornell University Press.

Gowa JS (1983) Closing the Gold Window: Domestic Politics and the End of Bretton Woods. Ithaca: Cornell University Press.

Grovogui SN (2006) Beyond Eurocentrism and Anarchy: Memories of International Order and Institutions. New York: Palgrave Macmillan.

Guilhot N (2014) Imperial Realism: Post-War IR Theory and Decolonisation. The International History Review 36(4): 698-720.

Guzzini S (2004) The Enduring Dilemmas of Realism in International Relations. European Journal of International Relations 10(4): 533-568.

Guzzini S (2013) The ends of International Relations theory: Stages of reflexivity and modes of theorizing. European Journal of International Relations 19(3): 521-541.

Gvalia G, Lebanidze B and Siroky DS (2019) Neoclassical realism and small states: systemic constraints and domestic filters in Georgia's foreign policy. East European Politics 35(1): 2151.

Hadfield-Amkhan A (2010) British Foreign Policy, National Identity, and Neoclassical Realism. Lanham: Rowman \& Littlefield.

Haskel BG (1980) Access to society: a neglected dimension of power. International Organization 34(1): 89-120.

He K (2017) Explaining United States-China relations: neoclassical realism and the nexus of threatinterest perceptions. The Pacific Review 30(2): 133-151.

Henderson EA (2013) Hidden in plain sight: racism in international relations theory. Cambridge Review of International Affairs 26(1): 71-92.

Henderson EA (2017) African Realism? International Relations Theory and Africa's Wars in the Postcolonial Era. London: Rowman \& Littlefield.

Hobson JM (2012) The Eurocentric Conception of World Politics: Western International Theory, 17602010. New York: Cambridge University Press.

Hoffmann S (1977) An American Social Science: International Relations. Daedalus 106(3): 41-60.

Hurrell A (2016) Towards the Global Study of International Relations. Revista Brasileira de Politica Internacional 59(2). DOI: 10.1590/0034-7329201600208. 
Inoguchi T (2009) Why are there no non-Western theories of international relations? The case of Japan. In: Acharya A and Buzan B (eds) Non-Western International Relations Theory: Perspectives on and beyond Asia. London: Routledge, pp. 51-68.

Jackson PT (2010) The Conduct of Inquiry in International Relations: Philosophy of Science and Its Implications for the Study of World Politics. London: Routledge.

Jackson PT and Nexon DH (2004) Constructivist Realism or Realist-Constructivism? International Studies Review 6(2): 337-341.

Johnston Al (2012) What (If Anything) Does East Asia Tell Us About International Relations Theory? Annual Review of Political Science 15(1): 53-78.

Juneau T (2015) Squandered Opportunity: Neoclassical Realism and Iranian Foreign Policy. Stanford: Stanford University Press.

Kalpakian J (2008) Ibn Khaldun's influence on current international relations theory. The Journal of North African Studies 13(3): 363-376.

Keohane RO (1988) International Institutions: Two Approaches. International Studies Quarterly 32(4): 379-396.

King G, Keohane RO and Verba S (1994) Designing Social Inquiry: Scientific Inference in Qualitative Research. Princeton: Princeton University Press.

Kirshner J (2012) The tragedy of offensive realism: Classical realism and the rise of China. European Journal of International Relations 18(1): 53-75.

Kitchen N (2010) Systemic pressures and domestic ideas: a neoclassical realist model of grand strategy formation. Review of International Studies 36(1): 117-143.

Korolev A and Portyakov V (2018) China-Russia Relations in Times of Crises: A Neoclassical Realist Explanation. Asian Perspective 42(3): 411-437.

Krasner SD (1977) Domestic Constraints on International Economic Leverage. In: Knorr K and Trager FN (eds) Economic Issues and National Security. Lawrence: Regents Press of Kansas, pp. 160181.

Krishna S (2001) Race, Amnesia, and the Education of International Relations. Alternatives: Global, Local, Political 26(4): 401-424.

Kristensen PM (2018) International Relations at the End: A Sociological Autopsy. International Studies Quarterly 62(2): 245-259.

Larsen, Henrik BL (2019) NATO's Democratic Retrenchment: Hegemony After the Return of History. New York: Routledge.

Legro JW and Moravcsik A (1999) Is Anybody Still a Realist? International Security 24(2): 5-55.

Levy JS (2008) Case Studies: Types, Designs, and Logics of Inference. Conflict Management and Peace Science 25(1): 1-18. 
Ling LHM (2014) The Dao of World Politics: Towards as post-Westphalian, worldist International Relations. London: Routledge.

Lobell SE, Ripsman NM and Taliaferro JW (eds) (2009) Neoclassical Realism, the State, and Foreign Policy. Cambridge: Cambridge University Press.

Long D and Schmidt BC (eds) (2005) Imperialism and Internationalism in the Discipline of International Relations. Albany: SUNY Press.

Mamdani M (2018) The African University. London Review of Books 40(14): 29-32.

Mearsheimer JJ (2003/2014) The Tragedy of Great Power Politics. New York: W.W. Norton \& Company.

Mearsheimer JJ and Walt SM (2013) Leaving theory behind: Why simplistic hypothesis testing is bad for International Relations. European Journal of International Relations 19(3): 427-457.

Meibauer, Gustav (2020) Interests, ideas, and the study of state behaviour in neoclassical realism. Review of International Studies 46(1): 20-36.

Moore CE (2011) Governing Parties and Southern Internationalism: a neoclassical realist approach to the foreign policies of South Africa and Brazil, 1999-2010. The London School of Economics and Political Science, London. Available at: http://etheses.Ise.ac.uk/196/ (accessed 22 November 2018).

Morgenthau HJ (1948/1993) Politics Among Nations: The Struggle for Power and Peace. Brief Edition. Boston: McGraw-Hill.

Mouritzen H (2017) Combining 'incompatible' foreign policy explanations: how a realist can borrow from constructivism. Journal of International Relations and Development 20(3): 631-658.

Narizny K (2017) On Systemic Paradigms and Domestic Politics: A Critique of the Newest Realism. International Security 42(2): 155-190.

Nau HR (2012) Introduction: Domestic Voices of Aspiring Powers. In: Nau HR and Ollapally DM (eds) Worldviews of Aspiring Powers: Domestic Foreign Policy Debates in China, India, Iran, Japan and Russia. Oxford: Oxford University Press, pp. 3-35.

Niebuhr R (1959) The Structure of Nations and Empires. New York: Charles Scribner's Sons.

Ollapally DM and Rajagopalan R (2012) India: Foreign Policy Perspectives of an Ambiguous Power. In: Nau HR and Ollapally DM (eds) Worldviews of Aspiring Powers: Domestic Foreign Policy Debates in China, India, Iran, Japan and Russia. Oxford: Oxford University Press, pp. 73-113.

Onea T (2012) Putting the 'Classical' in Neoclassical Realism: Neoclassical Realist Theories and US Expansion in the Post-Cold War. International Relations 26(2): 139-164.

Quinn A (2013) Kenneth Waltz, Adam Smith and the Limits of Science: Hard choices for neoclassical realism. International Politics 50(2): 159-182.

Rajagopalan R (1999) Neorealist theory and the India-Pakistan conflict-II. Strategic Analysis 22(10): 1525-1536. 
Rathbun B (2008) A Rose by Any Other Name: Neoclassical Realism as the Logical and Necessary Extension of Structural Realism. Security Studies 17(2): 294-321.

Resende-Santos J (2007) Neorealism, States, and the Modern Mass Army. New York: Cambridge University Press.

Ripsman NM, Taliaferro JW and Lobell SE (2016) Neoclassical Realist Theory of International Politics. New York: Oxford University Press.

Rösch F and Watanabe A (2017) Approaching the unsynthesizable in international politics: Giving substance to security discourses through basso ostinato? European Journal of International Relations 23(3): 609-629.

Rose G (1998) Neoclassical Realism and Theories of Foreign Policy. World Politics 51(1): 144-172.

Sabaratnam M (2011) IR in Dialogue ... but can we change the subjects? A typology of decolonising strategies for the study of world politics. Millennium 39(3): 781-803.

Sampson AB (2002) Tropical Anarchy: Waltz, Wendt, and the Way We Imagine International Politics. Alternatives: Global, Local, Political 27(4): 429-457.

Sari AC (2019) A neoclassical realist explanation of Indonesia's involvement in Muslim-related secessions in non-Muslim countries. Asian Journal of Comparative Politics 4(3): 213-241.

Sarkar BK (1919) Hindu Theory of International Relations. American Political Science Review 13(3): 400-414.

Schmidt BC (2002) Anarchy, World Politics and the Birth of a Discipline: American International Relations, Pluralist Theory and the Myth of Interwar Idealism. International Relations 16(1): 9-31.

Schmidt BC (2014) A Realist View of the Eurocentric Conception of World Politics. Millennium 42(2): 464-471.

Schweller R (2018) Opposite but Compatible Nationalisms: A Neoclassical Realist Approach to the Future of US-China Relations. The Chinese Journal of International Politics 11(1): 23-48.

Sears NA (2017) The neoclassical realist research program: Between progressive promise and degenerative dangers. International Politics Reviews 5(1): 21-31.

Seth S (2011) Postcolonial Theory and the Critique of International Relations. Millennium 40(1): 167183.

Shahi D (2018) Advaita as a Global International Relations Theory. London: Routledge.

Shahi D (2019a) Introducing Sufism to International Relations Theory: A preliminary inquiry into epistemological, ontological, and methodological pathways. European Journal of International Relations 25(1): 250-275.

Shahi D (2019b) Kautilya and Non-Western IR Theory. London: Palgrave Macmillan.

Shambaugh D and Xiao R (2012) China: The Conflicted Rising Power. In: Nau HR and Ollapally DM (eds) Worldviews of Aspiring Powers: Domestic Foreign Policy Debates in China, India, Iran, Japan and Russia. Oxford: Oxford University Press, pp. 36-72. 
Shani G (2008) Toward a Post-Western IR: The Umma, Khalsa Panth, and Critical International Relations Theory. International Studies Review 10(4): 722-734.

Sherrill CW and Hough RA (2015) Current Japanese Security Policy towards China and Neoclassical Realism: Testing IR Theories. Journal of Asian Security and International Affairs 2(3): 237265.

Shilliam R (ed) (2010) International Relations and Non-Western Thought: Imperialism, colonialism and investigations of global modernity. Abingdon: Routledge.

Skocpol T (1979) States and Social Revolutions: A Comparative Analysis of France, Russia, and China. Cambridge: Cambridge University Press.

Smith K (2016) Realist Foreign Policy Analysis with a Twist: The Persian Gulf Security Complex and the Rise and Fall of Dual Containment. Foreign Policy Analysis 12(3): 315-333.

Smith K (2018) Reshaping international relations: theoretical innovations from Africa. In: Aydinli E and Biltekin G (eds) Widening the World of International Relations: Homegrown Theorizing. Abingdon: Routledge, pp. 142-156.

Smith NR (2016) The EU under a realist scope: Employing a neoclassical realist framework for the analysis of the EU's Deep and Comprehensive Free Trade Agreement offer to Ukraine. International Relations 30(1): 29-48.

Smith NR (2018) Can Neoclassical Realism Become a Genuine Theory of International Relations? The Journal of Politics 80(2): 742-749.

Snyder GH (1996) Process Variables in Neoclassical Realist Theory. In: Frankel B (ed) Realism: Restatements and Renewal. London: Frank Cass, pp. 167-192.

Sørensen CTN (2013) Is China Becoming More Aggressive? A Neoclassical Realist Analysis. Asian Perspective 37(3): 363-385.

Steinsson S (2017) Neoclassical Realism in the North Atlantic: Explaining Behaviors and Outcomes in the Cod Wars. Foreign Policy Analysis 13(3): 599-617.

Sterling-Folker J (2002) Realism and the Constructivist Challenge: Rejecting, Reconstructing, or Rereading. International Studies Review 4(1): 73-97.

Sterling-Folker J (2009) Neoclassical realism and identity: peril despite profit across the Taiwan Strait. In: Lobell SE, Ripsman NM and Taliaferro JW (eds) Neoclassical Realism, The State, and Foreign Policy. Cambridge: Cambridge University Press, pp. 99-138.

Taliaferro JW (2000) Security Seeking under Anarchy: Defensive Realism Revisited. International Security 25(3): 128-161.

Taliaferro JW (2006) State Building for Future Wars: Neoclassical Realism and the ResourceExtractive State. Security Studies 15(3): 464-495.

Thakur V (2015) Africa and the Theoretical Peace in IR. International Political Sociology 9(3): 213229. 
Thakur V and Vale P (2020) South Africa, Race and the Making of International Relations. London: Rowman \& Littlefield.

Tickner AB (2013) Core, periphery and (neo)imperialist International Relations. European Journal of International Relations 19(3): 627-646.

Tickner AB and Smith K (eds) (2020) International Relations from the Global South: Worlds of Difference. London: Routledge.

Tickner AB and Waever O (eds) (2009) International Relations Scholarship Around the World. London: Routledge.

Tieku TK (2012) Collectivist Worldview: Its Challenge to International Relations. In: Cornelissen S, Cheru F and Shaw TM (eds) Africa and International Relations in the 21st Century. Basingstoke: Palgrave Macmillan, pp. 36-50.

Tingyang Z (2006) Rethinking Empire from a Chinese Concept 'All-under-Heaven' (Tian-xia). Social Identities 12(1): 29-41.

Verma R (2013) The tiger and the dragon: a neoclassical realist perspective of India and China in the oil industry in West Africa. The London School of Economics and Political Science, London. Available at: http://etheses.Ise.ac.uk/794/ (accessed 22 November 2019).

Vitalis R (2015) White World Order, Black Power Politics: The Birth of American International Relations. Ithaca: Cornell University Press.

Vukovich DF (2011) China and Orientalism: Western Knowledge Production and the P.R.C. Abingdon: Routledge.

Waever $O$ and Tickner AB (2009) Introduction: geocultural epistemologies. In: Tickner AB and Waever O (eds) International Relations Scholarship Around the World. London: Routledge, pp. 1-31.

Waltz KN (1954/2001) Man, the State, and War: A Theoretical Analysis. New York: Columbia University Press.

Waltz KN (1979) Theory of International Politics. New York: McGraw Hill.

Wendt A (1999) Social Theory of International Politics. Cambridge: Cambridge University Press.

Whyte C (2019) Can We Change the Topic, Please? Assessing the Theoretical Construction of International Relations Scholarship. International Studies Quarterly 63(2): 432-447.

Wivel A (2005) Explaining why state X made a certain move last Tuesday: the promise and limitations of realist foreign policy analysis. Journal of International Relations and Development 8(4): 355-380.

Wivel A (2016) Living on the edge: Georgian foreign policy between the West and the rest. Third World Thematics: A TWQ Journal 1(1): 92-109.

Wohlforth WC (1993) The Elusive Balance: Power and Perceptions During the Cold War. Ithaca: Cornell University Press. 
Yang S (2013) Power Transition, Balance of Power, and the Rise of China: A Theoretical Reflection about Rising Great Powers. China Review 13(2): 35-66.

Zakaria F (1998) From Wealth to Power: The Unusual Origins of America's World Role. Princeton: Princeton University Press.

Zhang C (2017) Review Essay: How to Merge Western Theories and Chinese Indigenous Theories to Study Chinese Politics? Journal of Chinese Political Science 22(2): 283-294.

Zhang F (2012) The Tsinghua Approach and the Inception of Chinese Theories of International Relations. The Chinese Journal of International Politics 5(1): 73-102. 